UDC 159.928

DOI: https://doi.org/10.17721/upi.2019.2(12).7

Korolov D. K.,

PhD (Candidate of Psychological Sciences),

Associate Professor (docent),

Social Psychology Department,

Taras Shevchenko National University of Kyiv

E-mail: assessment@i.va

ORCID: 0000-0002-9685-5286

Researcher ID: F-1717-2018

\title{
DEVELOPMENT OF THE GIFTED STUDENTS' PERSONAL VALUES QUESTIONNAIRE
}

У представленій статті описано перший етап розробки опитувальника особистісних цінностей обдарованих студентів. Зазначений опитувальник необхідний, оскільки традиційні методики для дослідження особистісних цінностей мають дуже широку спрямованість, отже, не можуть відобразити особистісні особливості обдарованих. Останні, ймовірно, внутрішньо пов' язані із психологічним змістом обдарованості.

Опитувальник заснований на результатах раніше проведеного структурованого глибинного інтерв' ю зі студентами та успішними професіоналами, що стосувалось їхного стилю життя та цінностей. Виділені ціннісні типи, їхні характеристики стали підставою для формулювання пунктів опитувальника.

Опитувальник апробовано на студентський вибірці чисельністю 137 осіб. Конструктну валідність методики підтверджено результатами факторного аналізу, який надав змістовно чітку структуру з семи ортогональних компонент. Зокрема, виділено такі ціннісні паттерни: продуктивна творча діяльність; соціальне визнання; кар'єрні досягнення; емоційна насиченість життя; ціннісна невизначеність; комфортні умови життя; суб' єктивний комфорт.

Зазначені результати створили основу для конструювання відповідних шкал опитувальника. Останні мають достатню внутрішню узгодженість, коефіцієнт альфа Кронбаха варіюється в межах 0,69-0,80. Коефіцієнти дискримінативності пунктів, що формують шкали, також не менші 0,20, що відповідає психометричним вимогам.

Наступні дослідження, що необхідні для завершення конструювання методики, мають зосередитись на аналізі розподілу відповідей за пунктами, визначенні ретестової надійності, поглибленому вивченні валідності та розробці статистичних норм. 


\section{Ключові слова: обдарованість, обдарована особистість, особистість, особистісні цінності, психодіагностика обдарованості, особистісний опитувальник.}

Problem challenge. Despite the fact that personal values are actively studied empirically in different countries during the last decades, a standardized tool for psychological diagnostics of gifted people's values has not been developed yet. The available techniques cover the widest possible range of values. Their questions are formulated in a very general way so that they are clear and understandable for very different people belonging to different cultures. As a result, specific accents characteristic for values of gifted people, their particular vision of the world cannot be reflected in the results obtained with such techniques. Therefore, there is a need to develop a standardized tool to diagnose personal values characteristic for gifted students in the cultural context of modern Ukraine.

Analysis of recent research and publications. Today, personal values are studied primarily in line with the approach developed by Sh. Schwartz [6], but empirical studies of gifted people's values are nearly absent. Only, the study performed E. Pollet and T. Schnell on subjective well-being and life-meanings of intellectually gifted people was published recently [5].

The Laboratory of the Psychology of Giftedness at Kostiuk Institute of Psychology (Ukraine) conducts the research on gifted people's values; the presented in the article study was performed within the framework of the laboratory approach [4]. We also used Schwartz' methodical approach, implemented in Schwartz Value Inventory, to design our standardized tool. In particular, according to Schwartz's theory, personal values are presented at two levels: normative ideals and individual priorities. The second level corresponds to specific human actions [1, p. 34]. Schwart'z Inventory studies both levels. However, in the context of the studied giftedness, the second level is more important, as it has a regulatory influence on a gifted individual's behaviour.

The list of the measured constructs and their contents were determined based on in-depth interviews conducted to identify the specificity of gifted people's value sphere [3].

The traditional psychometric technologies were used for questionnaire designing [2].

The article purpose. The purpose of the presented research is to develop a first version of the questionnaire that reveals gifted students' personal values. The following tasks should be solved to achieve this purpose: to define a diagnostic construct and corresponding empirical indicators (questionnaire 
statements); to determine the questionnaire factor structure; to estimate internal consistency of scales and to perform discriminative analysis.

Presentation of the main material. The initial designing step is to describe the diagnostic construct and formulate statements. As noted above, this step is based on the results of previously conducted in-depth interviews [3].

The questionnaire aim was to measure students' value styles that appear often and encompass certain constellations of values; each of these constellations, in turn, is diagnosed with the help of two reference points:

I. Focus on life emotionality.

1. New impressions.

a) I like to search something new, I can't stay in place.

b) It is important for me that every day is filled with impressions, emotions.

2. Vivid experiences.

a) I strive for a diverse, vibrant life.

b) I always need to find something that would fill my life.

3. Emotional comfort.

a) I am distracted to be comfortable, feel at ease.

b) It is important to go somewhere, do something to lift the spirits.

4. Nice conversations.

a) I like to communicate with interesting people.

b) It is important for me to be among bright personalities.

5. Popularity.

a) I like being at the centre of events.

b) The attention and admiration of others is important to me.

6. Avoidance of monotony and routine.

a) I prefer to rest, not to be overloaded by learning, work or problems.

b) If I do not like something, I try not to do it.

II. Focus on comfortable living conditions.

1. Money.

a) It seems to me that everything is settled by money.

b) If you have money, you can enjoy life.

2. Useful contacts.

a) It is important to find the people who will solve your problems.

b) It is good when there is someone helping you with your life.

3. Comfortable work.

a) I wish I didn't have to work.

b) It is important that your occupation does not prevent life enjoyments.

4. Comfortable lifestyle, comfortable environment. 

for life.

a) I would like to move to another country that is more comfortable

b) It is important to have a lot of free time to fulfil own desires.

5. Relationships without problems and tension.

a) I would like to have relationships without problems and tension.

b) I want to have relationships that would not limit me and allow me to live freely.

6. Refusal to commitments.

a) I do not consider it necessary to make a commitment to anyone.

b) I don't want to be obliged to anyone.

7. Refusal to solve problems if they demand maximal mobilization of forces.

a) A reasonable person solves problems easily.

b) You should not worry over problems; many of them will be solved over time.

8. Avoiding internal conflicts and hard experiencing.

a) You should not focus too much on problems.

b) It is better not to think of bad.

III. Value uncertainty.

1. Absence of conscious stable personal values.

a) I question everything, even my beliefs.

b) I am interested in everything a little.

2. Multidirectional activities.

a) There are constant hesitations in my life.

b) My life has no a clear orientation.

3. Awareness of insufficiency of clear guidelines in one's life.

a) I don't want to do anything, so I don't do anything.

b) I don't know what I want in life.

IV. Focusing on a utilitarian lifestyle.

1. Career.

a) Professional work should be at the forefront.

b) My professional career is my life priority.

2. Family.

a) I want to have a good family.

b) I want to build my own family.

3. Stereotype approaches.

a) I am calm about creativity.

b) I believe that creativity can be pursued when a person is already self-realized in more important areas.

4. Rational ways of problem solving.

a) Time cannot be wasted; it should be spent with benefits. 
b) Everything in life should be done according to plan.

5. Economy of efforts.

a) It is not necessary to "reinvent the wheel", it is necessary to base oneself upon experiences of others.

b) Attempts to find something new can interfere with the useful life results.

$\mathrm{V}$. Values of productive work.

1. Persistent work.

a) I devote most of my time and energy to my profession.

b) The main priority is constant work and development.

2. Activity efficiency.

a) It is important for me to get good work results.

b) I am happy when I do a great job.

3. Achievements.

a) It is important for me to achieve what others are not capable of.

b) I am happy if I reach a result that is not accessible to everyone.

4. Social recognition.

a) It is important that others value my work.

b) I seek for recognition of my achievements.

5. Pleasure of the work performed.

a) The most gratifying feeling is a sense of accomplishment.

b) When I successfully complete my work, it is extremely uplifting.

VI. Focus on immersion into activities.

1. Internal interest.

a) My profession is my main life passion.

b) It is extremely important for me that my job is what I like.

2. Usefulness of work.

a) I like when what I have done benefits others.

b) It is important that my work results are recognized by others.

3. New knowledge.

a) I like to discover something new.

b) It is necessary to find out something that I did not know before.

4. Creativity.

a) I like to create something new out of nothing.

b) For me, a creator's joy is self-realization.

5. Constant self-development, moving forward.

a) It is important for me to say to myself from time to time: now, I can do new things, I have new skills.

b) I really value the constant movement forward, the ability to reach a new level.

6. Internal freedom. 
a) In all circumstances, I must be able to move forward.

b) I myself determine a direction of my further development.

The developed questionnaire was tested on the sample of students studied at Taras Shevchenko National University of Kyiv in different specialties. The total number of respondents was 137 (108 women and 29 men), aged 17-24, with an average age of 19.9 years. The survey was conducted on a voluntary basis.

The students understood the instructions and the statements without difficulties.

In order to determine the psychometric qualities of the questionnaire, the obtained data were processed mathematically using the SPSS statistical package. In particular, the construct validity of the questionnaire was checked, for which the factor analysis with the principal component method and the varimax rotation was used for all statements. The number of factors was determined by the scree plot (Fig. 1).

The structure of seven factors was substantially interpreted. The solutions consisting of eight or more factors, as compared to the seven-factor structure, do not contain other substantial components, and the factors following after the seventh factor duplicate the previous ones. The structure of the seven factors is then analyzed (Appendix A).

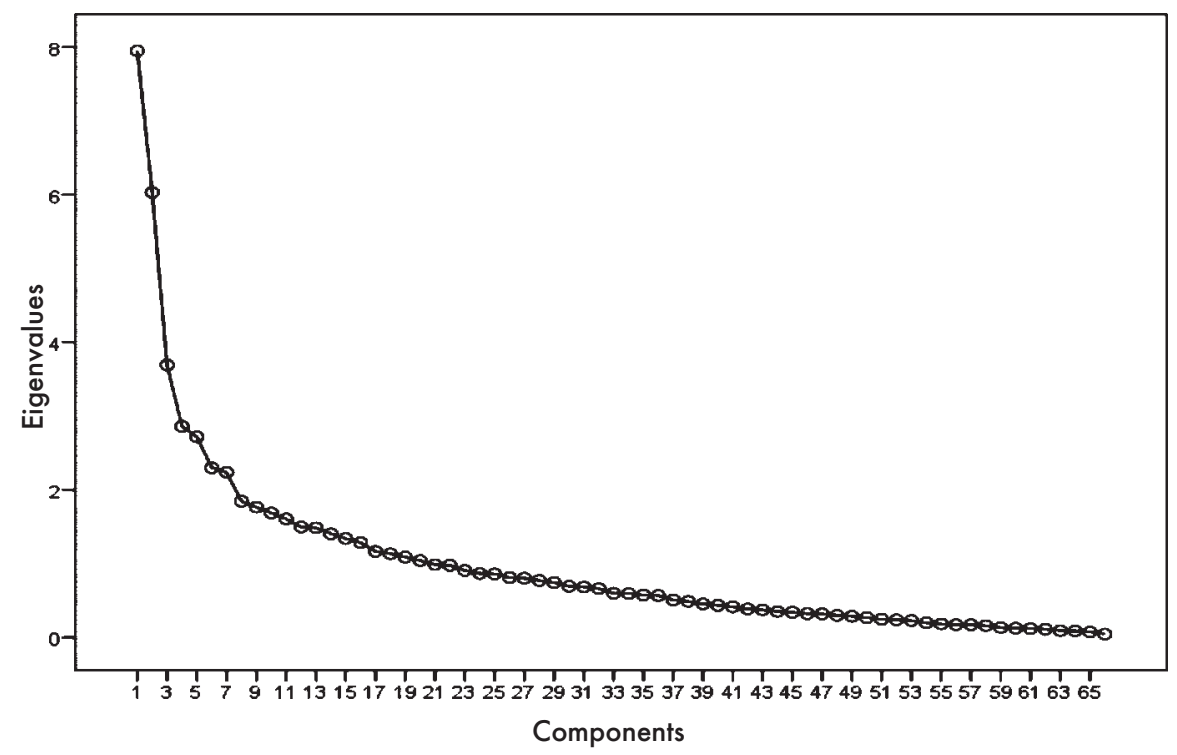

Fig. 1. Scree plot 
This solution explains $42.1 \%$ of the total variance. The first factor, named "Life Emotionality", explains $8.03 \%$ of the variance and includes the following statements (ordered by load reduction): "I like to discover something new"; "I strive for a diverse, vibrant life"; "It is important for me that every day is filled with impressions, emotions"; "I like to search something new, I can't stay in place"; "In all circumstances, you need to be able to move forward"; "I like to communicate with interesting people"; "I always need to find something that would fill my life"; "The main priority is constant work and development"; "It is important for me to say to myself from time to time: now, I can do new things, I have new skills", "It is important for me to be among bright personalities"; "I really value the constant movement forward, the ability to reach a new level"; "Time cannot be wasted, it should be spent with benefits"; "It is important to go somewhere, do something to lift the spirits".

The second factor, "Productive creativity", explains $6.3 \%$ of the total variance and includes the following statements (ordered by load reduction): "It is necessary to find out something that I did not know before"; "When I successfully complete my work, it is extremely uplifting"; "It is important for me to get good work results"; "It is extremely important for me that my job is what I like"; "I am happy when I do a great job"; "I like when what I have done benefits others"; "I like to create something new out of nothing"; "For me, a creator's joy is self-realization"; "I myself determine a direction of my further development".

The third factor, "Social recognition", explains $5.9 \%$ of the total variance, is determined by the statements: "It is important that the my work results are recognized by others"; "I seek for recognition of my achievements"; "The attention and admiration of others is important to me"; "It is important that others value my work"; "I like being at the centre of events".

The fourth factor, "Comfortable living conditions", determines $5.9 \%$ of the variance and includes the following statements: "If you have money, you can enjoy life"; "I prefer to rest, not to be overloaded by learning, work or problems"; "It seems to me that everything is settled by money"; "It is good when there is someone helping you with your life"; "If I do not like something, I try not to do it"; "It is important to have a lot of free time to fulfil own desires"; "I would like to have relationships without problems and tension"; "It is important that your occupation does not prevent life enjoyments"; "I wish I didn't have to work"; "I am happy if I reach a result that is not accessible to everyone"; "I am distracted to be comfortable, feel at ease"; "I would like to move to another country that is more comfortable for life"; "It is important to find the people who will solve your problems". 
The fifth factor "Career achievements", determines $5.7 \%$ of the variance and includes the following statements: "Professional work should be at the forefront"; "Everything in life should be done according to plan"; "My professional career is my life priority"; "My profession is my main life passion"; "The most gratifying feeling is a sense of accomplishment"; "I devote most of my time and energy to my profession"; "I believe that creativity can be pursued when a person is already self-realized in more important areas"; "It is important for me to achieve what others are not capable of"; "Attempts to find something new can interfere with the useful life results".

The sixth factor, "Value uncertainty", determines $5.4 \%$ of the variance and includes the following statements: "My life has no a clear orientation"; "I want to build my own family" with the "minus" sign; "I don't know what I want in life"; "I want to have a good family" with the "minus" sign; "There are constant hesitations in my life"; "I want to have relationships that would not limit me and allow me to live freely"; "I want to have relationships that would not limit me and allow me to live freely"; "I question everything, even my beliefs".

The seventh factor, "Subjective comfort", explains $4.9 \%$ of the total variance and includes the following statements: "You should not worry over problems; many of them will be solved over time"; "You should not focus too much on problems"; "I don't want to be obliged to anyone"; "It is better not to think of bad"; "I do not consider it necessary to make a commitment to anyone"; "A reasonable person solves problems easily".

The presented results of factor analysis became the basis for the scales having the same names. The criterion for statement assigning to the scale is the relevant factor load of 0.30 or higher. With this criterion, three statements were not included into any scale - "It is not necessary to reinvent the wheel, it is necessary to base oneself upon experiences of others"; "I am interested in everything a little"; "I am calm about creativity".

In addition, six items were not included in the Life Emotionality Scale. Four of them are simultaneously included into the factor of creative values: "I really value the constant movement forward, the ability to reach a new level"; "The main priority is to constantly pursue and develop"; "In all circumstances, I must be able to move forward"; "Time cannot be wasted; it should be spent with benefits". The statement of "It is important for me to be among bright personalities" is added to the factor of social recognition. The statement of "It is important for me to say to myself from time to time: now, I can do new things, I have new skills", reflects other value - a focus on development.

The internal consistency of the scales was then checked. A statement should be excluded if it correlation with the total score obtained without 
contribution of the examined statement is less than 0.20. All statements, except one - "I am happy if I reach a result that is not accessible to everyone", are acceptable.

The internal consistency of the scales - Cronbach's alpha coefficients are also acceptable: the scale of focus on life emotionality is 0.80 ; the scale of creativity values is 0,69 ; the social recognition value scale is 0.79 ; the scale of focus on comfortable living conditions is 0.77 ; the career value scale 0.73 ; the scale of uncertainty is 0.68 ; the scale of focus on subjective comfort is 0.70 .

Conclusions. A standardized tool for psychological diagnostics of gifted people's values has not been developed yet. Specific accents characteristic for values of gifted people, their particular vision of the world cannot be reflected with the available methods for studying of values. In order to solve this problem, the development of the questionnaire revealing gifted students' values was initiated; it help diagnose the personal values characteristic for gifted youth in the cultural context of modern Ukraine.

The described diagnostic construct and the developed questionnaire statements are based on the results of the in-depth interviews conducted earlier with the aim to clarify the specifics of gifted people's value sphere.

The developed questionnaire was tested on the sample of 137 students studied at Taras Shevchenko National University of Kyiv. The construct validity of the questionnaire was confirmed with the performed factor analysis, which revealed the substantially clear structure consisted of seven orthogonal components. In particular, the following value patterns were singled out: productive creativity; social recognition; career achievements; life emotionality; value uncertainty; comfortable living conditions; subjective comfort.

The identified value patterns became the basis for the relevant questionnaire scales. The latter have sufficient internal consistency. The discriminative coefficients for the statements forming the scales also meet the psychometric requirements.

The prospects for further research are related to the questionnaire standardization, its retest reliability, and the in-depth study of its construct validity.

\section{Список використаних джерел}

1. Карандашев В. Н. Методика Шварца для изучения ценностей личности: концепция и методическое руководство / В. Н. Карандашев. - СПб.: Речь, 2004. - 70 с.

2. Клайн П. Справочное руководство по конструированию тестов / П. Клайн. К.: ПАН-Лтд, 1994. - 286 с. 
3. Корольов Д. К. Особистісні цінності інтелектуально обдарованої особистості / Д. К. Корольов // Актуальні проблеми психології. - 2018. - Т. VI, Випуск 14. C. $137-152$.

4. Музика О. Л. Аксіогенез особистості і розвиток обдарованості: теоретична модель і підходи до дослідження / О. Л. Музика // Актуальні проблеми психологіï. - 2018. - Т. VI, Випуск 14. - С. 60-76.

5. Pollet E. Brilliant: But What For? Meaning and Subjective Well-Being in the Lives of Intellectually Gifted and Academically High-Achieving Adults / Edith Pollet, Tatjana Schnell // Journal of Happiness Studies. - 2017. - Vol. 18, Issue 5. - P. 1459-1484.

6. Sagiv L. Personal Values in Human Life / L. Sagiv, S. Roccas, J. Cieciuch, Shalom H. Schwartz // Nature Human Behaviour. - 2017. - Issue 1. - P. 630-639.

\title{
References transliterated
}

1. Karandashev V. N. Metodika Shvarca dlja izuchenija cennostej lichnosti: koncepcija i metodicheskoe rukovodstvo / V. N. Karandashev. - SPb.: Rech', 2004. - 70 s.

2. Klajn P. Spravochnoe rukovodstvo po konstruirovaniju testov / P. Klajn. - K.: PAN-Ltd, 1994. - $286 \mathrm{~s}$.

3. Korol'ov D. K. Osobystisni cinnosti intelektual'no obdarovanoi' osobystosti / D. K. Korol'ov // Aktual'ni problemy psyhologii'. - 2018. - T. VI, Vypusk 14. S. $137-152$.

4. Muzyka O. L. Aksiogenez osobystosti i rozvytok obdarovanosti: teoretychna model' i pidhody do doslidzhennja / O. L. Muzyka // Aktual'ni problemy psyhologii'. - 2018. T. VI, Vypusk 14. - S. 60-76.

5. Pollet E. Brilliant: But What For? Meaning and Subjective Well-Being in the Lives of Intellectually Gifted and Academically High-Achieving Adults / Edith Pollet, Tatjana Schnell // Journal of Happiness Studies. - 2017. - Vol. 18, Issue 5. - P. 1459-1484.

6. Sagiv L. Personal Values in Human Life / L. Sagiv, S. Roccas, J. Cieciuch, Shalom H. Schwartz // Nature Human Behaviour. - 2017. - Issue 1. - P. 630-639.

\section{A b s t r a c t}

\author{
Korolov D. K., \\ $\mathrm{PhD}$ (Candidate of Psychological Sciences), \\ Associate Professor (docent), \\ Social Psychology Department, \\ Taras Shevchenko National University of Kyiv \\ E-mail: assessment@i.va
}

\section{DEVELOPMENT OF THE GIFTED STUDENTS' PERSONAL VALUES QUESTIONNAIRE}

The purpose of the presented research is the development of a questionnaire for gifted individuals' values assessment. This instrument is needed because the general personal values questionnaire has a very broad focus and 
cannot assess specific personal preferences of gifted individuals. Probably, those preferences are internally connected with the nature of giftedness.

The instrument is based on previously conducted in-depth structured interviews with students and successful professionals on their personal lifestyle and values. The highlighted personal values types, their features create a basis for the questionnaire item development.

The first questionnaire version was tested on a sample of 137 students. The instrument's construct validity is confirmed by results of factor analysis, which provided a meaningful and bright structure of seven orthogonal factors. They describe the following specific value patterns: intensive emotional experience; productive creative activity; social recognition; comfortable living conditions; career achievements; value uncertainty; subjective comfort.

These results created the basis for relevant scales development. Those scales show enough internal consistency, the alpha coefficient is in the range from 0.69 to 0.80 . Also scales item discriminativeness is upper 0.20 that corresponds to the psychometric requirements.

The future researches will focus on item difficulty analysis, detailed studies of retest reliability and validity, test norm development.

Key words: giftedness, gifted personality, personality, personal values, giftedness assessment, personality questionnaire.

Отримано - 10 травня 2019

Received - May 10, 2019
Рецензовано - 19 травня 2019

Revision - May 19, 2019
Прийнято - 25 травня 2019

Accepted - May 25, 2019 